\title{
LOAN RISK MANAGEMENT RELATED FORMS OF APPLICATION MODELS BY BANKING INSTITUTIONS
}

Shaqir Rexhepil

University of Tirana, Tirana, Albania

\section{ABSTRACT}

The study on the functioning of the models on the financial management of credit risk in banking institutions, is the special importance on developing strategic financial objectives and application of protective methods on predictions of risks which may be in credit to the economy and family businesses. Banks in their monetary program, among others anticipate increased demand for money by lending to the economy and their businesses. Support the economy with credit is one of the main tasks of the banking system, closely related to the specific conditions of this country. During the latter half of the current decade, the structure of banking system deposits has undergone significant changes, which have been largely a function of economic development, but also the phenomena and the development of the banking system itself. The general trend of the deposit system has been positive and graphs shows time series tables for their tendency. However, the problems of fragility and half the first decade of the establishment of a banking system crisis and the problems reflected in the structure and level of deposits in the banking system which is reflected by external and internal factors in the not functioning of Kosovo country.

\section{JEL CLASSIFICATION \& KEYWORDS}

- E5 E51 - LOAN RISK - BANKING INSTITUTIONS - TYPES OF LOAN - MANAGEMENT OF FINANCIAL RISK

\section{INTRODUCTION}

Role of management of loans is extremely important in economic progress and financial security of banks, we have also provided for, in this work, details of management of loans and their impact on the risk of the banking system. Forms of application and management of loans are of special importance for the sound functioning on the execution of strategic and financial objectives by banking institutions. In addition, the loan interest and their heights are determination parameters in the banking institutions. The oversight authority is of special importance in surveying, and is an indicator of the progress performance in the management of loans in banking institutions. Banks, in their monetary programme, among others, foresee increase of the request for money from the loan for economy and their businesses. Supporting the economy with loan is one of the main duties of the banking system, which is closely related to specific conditions of our country. Over the last half of the current decade, the structure of bank system deposits has suffered important changes, which in general have been the function of country's economic development, but also have been the phenomena and development of the banking system itself. The overall trend of system deposits was positive and charts indicate the tendency for their increase. However, fragility and problems of half of the first decade on the creation of the banking system are reflected in crises and structure problems and in the level of banking system ' shaqirrexhepi@hotmail.com deposits, which is reflected with external and internal factors in failing to entirely function in the economic stabilization.

Management of bad loan policies, interest, market and other economic parameters comprises indispensability in the achievement of objectives for financial stability and compliance with banking institutions' obligations in front of economic challenges and the Central Bank Authority. The information provided is mainly based on the analysis of materials according to time series. The form of calculation and its tendency have been described for each of the indicators, which have been recorded and explained later on (Financial stability and economic analysis (No.2), Central Bank of the Republic of Kosovo (CBRK, 2011)).

\section{Methodology of analysis}

Methodology used is mainly based on the analyses of materials, tables and graphs of time series. In addition, policies of different and central banks have been consulted on the management of loan risk. In addition, we have also included in our work different foreign volumes on the forms of loan risk management, for the application of loans, classification of commitments based on solvency. With loan able one means whether the commitments will be able to meet all obligations they reach and what is the highest amount possible of the product/ release that the bank is able to accord, namely what is the highest ceiling of entering into debt in the bank. Risks that may come for the height of interest implemented are analysed, as well as the forming of the amounts of reserves for potential losses.

\section{Management of loan risk and types of loan}

Banks should have a system for the management of loan risk, which is suitable to the nature, volume and complexity of their activities. System of loan risk management in banks should include policies, procedures, rules and structure which are used by banks to manage the loan risk. System of management of loan risk should constantly and timely conduct the assessment of quality of loans and other means, including the defining of adequacy of reserves for losses related to this risk (Pickett, 2005).

Categories determining loans of high risk level are:

- Loans with delay are defined loans classified in the category of classification of loans,such as: observation, under the standard, suspicious and loss;

- classified loans are defined as loans of the category of classification of loans, such as: under the standard, suspicious and loss;

- non-performing loans are defined as loans classified in the category of classification of loans, such as: suspicious and loss;

- reprogrammed loans are those loans which are reconstructed and are renegotiated between the bank and borrowers due to the deterioration of the financial 
situation of the borrower or the inability of the borrower to meet the original payment plan;

- interest on delay is defined as interest which is not paid prior to the loan is re-programmed, including the regular interest on delay, the penalty interest and other associated interests related to loan;

- regular interest on delay is defined as interest which is not paid prior to the loan is re-programmed, excluding the penalty interest and other associated interests related to loan;

- real market value is the price according to which an asset can be sold in the open free market, with the free will of the purchaser and vendor and with no pressure exercised to any of them (Methods on monetary and financial statistics (CBRK), 2011).

\section{Structure of loans and economic activity}

Structure of loans of enterprises according to economic activity in 2011 remained similar to previous years, where $71.7 \%$ of total loans for enterprises were issued to the sector of services. Out of the total loans issued for enterprises, loans for commercial enterprises, which are categorised within the sector of services represented $52.7 \%$ of the total of loans of the banking system. Loans for the industry sector, where mines, productivity and construction belong were represented by $24.8 \%$ in the structure of the total of loans (figure 1). While, loans for the agriculture sector were loans with the lowest participation by $3.5 \%$ in the total of loans (Annual report (p.44) (CBRK), 2011).

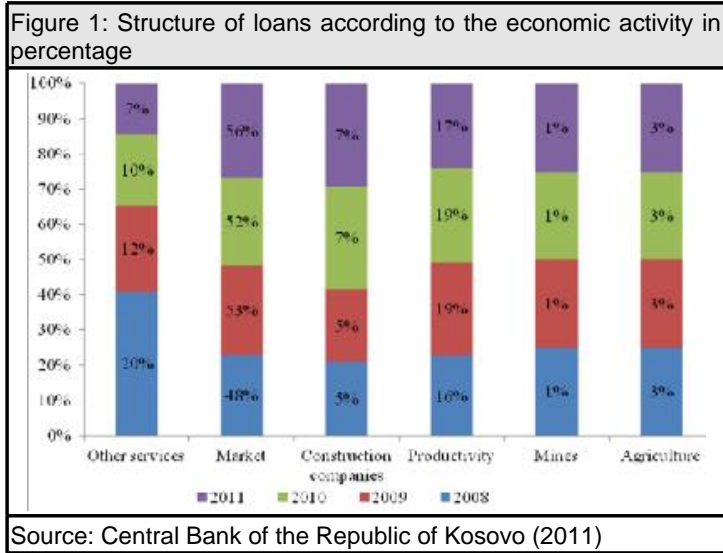

In 2011, loans with maturity date over two years to five years represented $41.98 \%$ of the total loans, while loans with the maturity date over five years to ten years represented $29.32 \%$ of total loans (figure 2 ).

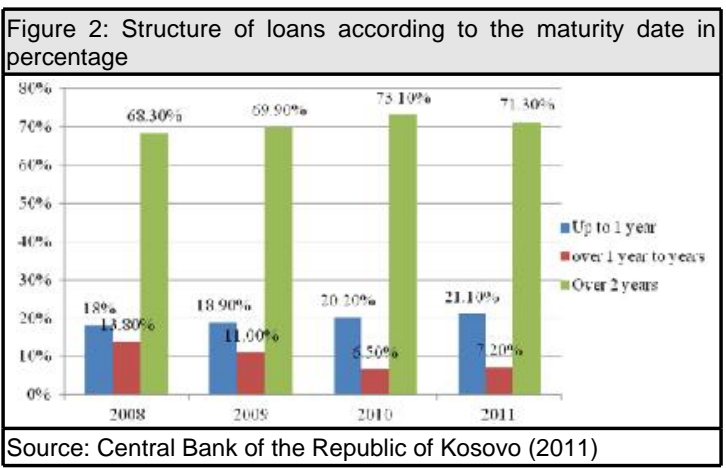

www.journals.cz
Considerable participation in the total of loans had also maturity loans up to one year, which represented $21.10 \%$ of the total of loans. While the remaining part of $7.20 \%$ was represented by the loans with maturity over one year up to two years (Annual report (p. 45) (CBRK), 2011).

In 2011, one noted a considerable increase of loans with maturity of up to one year $(21.10 \%)$, while one noted slowing down of the increase on loans with the maturity date over two years.

\section{Categories of classification according to the scale of loans risk}

Banks should review and classify exposures to loan risk at least on monthly basis. Banks may review and classify their portfolios more frequently.

Standard

All loans or other direct loan services and extra balance exposures carrying a normal bank risk. Information available related to the loan exposures, performance of the account of the client, and financial data, all these prove that the extinction of exposure is quite secure and there is no difficulty (or obligation is completely secured with appropriate collateral). Loan is active, or is not delayed more than thirty -30 days from the date of return or maturity date of loan. Overdrafts should be within the limits specified, or should only temporarily exceed the limit by $5 \%$ or less than 30 days, as well as cash flow in the current account is sufficient to pay the overdraft balance within 30 days from the date of expiry of overdraft (Regulation on management of loan risk (p.7) (CBRK), 2011).

Bad debts

Losses are those exposures based on an analysis of all associated factors of the loan with low value or will require an additional long period to execute some value and are no longer reasonable to be kept in the active ledgers of the bank.

An exposure may be considered as bad exposure (loss) if some of the criteria may be applied as follows:

- If deposits/ cash flow in the overdraft account of the client are insufficient to liquidate the overdraft balance not paid within 180 days from the day of the expiry of the overdraft;

- if the client exceeded the authorised limit of the product over $5 \%$ or more, for more than 180 days without paying this overdraft or if the management of the bank has not preliminary and formally authorised the increase of limit

- if the client is late to execute payment of whatever instalment contracted (including the interest) for more than 180 days

- if the date of return / date of expiry of loan is in arrears for more than 180 days for the reasons of non-payment (Manual on MFI Interest rate statistics regulation 2001/18, European Central Bank (ECB), 2003).

\section{Some statistics of loan risk}

During 2011, the best economy performance was reflected also on the best performance of the banking system, not only on the increase of the volume of crediting, but also on the improvement of the quality of crediting portfolio. The structure of loans according to classification based on quality continued to be similar with the previous year, there was even a slight displacement of loans from lower quality categories towards standard categories (standard category includes loans with no return problems). 
In (figure 3) one can notice that the participation of loans belonging to the standard category marked a slight increase compared to previous year and was at $90.0 \%$ for the total of loans for the banking system (89.7\% in December 2011). In December 2011, the loan participation classified as observation in the total of loans marked a decrease by $0.1 \%$ compared to previous year when it was $1.8 \%$. While, the category of loans under the standards remained unchanged and was at $2.6 \%$ of the total loan portfolio. In general, the participation of loans classified in the total loan portfolio marked a decrease in 2011, thus suggesting for a slight improvement of the quality of loans (Annual report ( $p$. 55) (CBRK), 2011) .

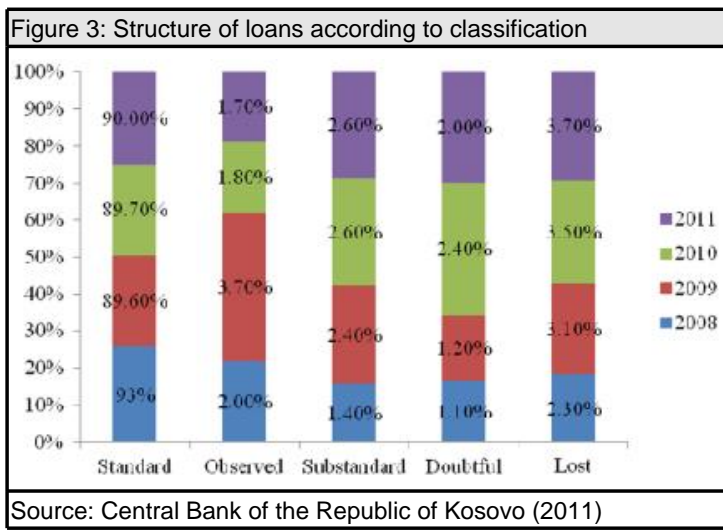

Structure of Non Performing Loans (NPL) continues to be dominated by loans classified as lost, which in December 2011 increased participation in $64.5 \%$ of the total of NPLs from $59.5 \%$ in December 2010. The remaining part of NPL is comprised of loans categorised as suspicious ones (figure 4). Over this period, the value of loans lost marked an annual increase by $23.1 \%$ (11.6 million euro), while suspicious loans decreased by 0.4 (130 thousand euros), compared to the previous year.

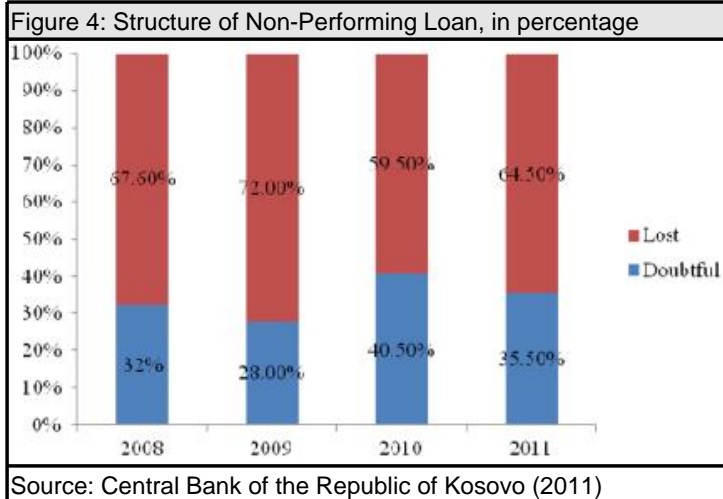

Total value of NPLs in December 2011 reached $€ 96.2$ million, which represents an annual increase by $13.6 \%$. Over this period 2009-2011, the average rate of the annual increase of NPLs was $36.5 \%$, while the average rate of the increase of the overall levels of loan was $12.8 \%$ (figure 5).

Out of the total eight banks operating in Kosovo, in 2011, five of them marked deterioration in the quality of the loan portfolio (increase of participation of NPL to the overall loan portfolio), while three banks reported improvement in the quality of loan portfolio.

www.journals.cz

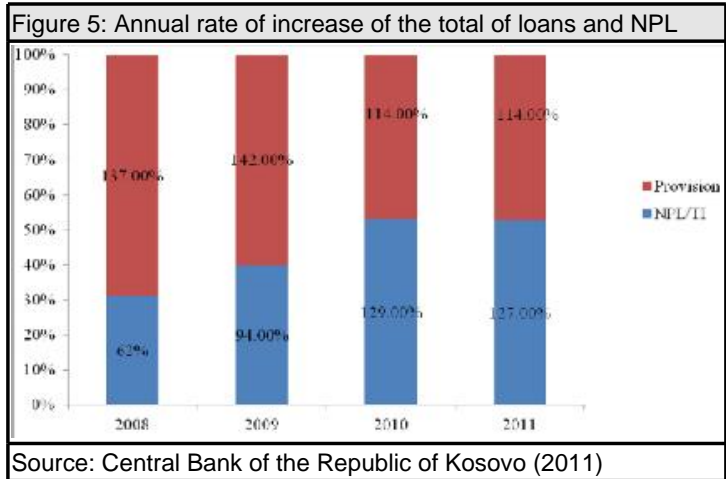

\section{Level of risks}

During this research, we have kept record of some deficiencies in its full development of the market of capital, technology development in dissemination of information, risk on the return of loans, non-favourable loans which have diminished the importance of these institutions. Geographic expansion, quantity and diversity of services, on-going publicity are the consequences of this increasing phenomenon. The active crediting of economy long expected, while selecting the more profitable projects, generates also numerous positive effects, some of which we will try to address below. Looking at them from a narrow viewpoint, a financial system's main purpose is to facilitate the dissemination and development of economic sources in time and space, in an unsecured economic environment. As a matter of fact, the identification of financial system only by the process of dissemination of the economic capital is not entirely accurate, because the financial system:

- Ensures the payment system for the exchange of goods;

- creates mechanisms to raise funds, to transfer these funds in time, in different regions and industries;

- provides administration of insecurity and control of risk;

- provides information assisting coordination of a decentralised decision-making in different sectors; and

- provides the possibility to alleviate asymmetry of information and problems of stimulus.

As a problem, this has to do with the inability of the bank to possess the same information (accurate information) that the borrower has on the potential return and on the risk of project. The situation of adverse selection occurs when bad borrowers - with poor economic projects and with high risk - are inclined to accept unfavourable conditions of loan. These creditors, having projects with high risk, are ready to accept high interest rates, because in case the project is finalised successfully, they will be the sole beneficiaries. Situation of moral risk may be encountered when the borrower have received loan and $s$ associated with the possibility of the inclusion of activities, which are unacceptable to the lender, since they increase the risk.

\section{CONCLUSION}

This material has analysed the latest developments in the banking system, with a special focus on the activity of policies on the flow of risk of loans. Crediting, the activity which is at the basis of development of the banking system, has gained momentum over the last years. It is assessed that the macroeconomic stability, placing of the trust of the public into the banking institutions under the careful oversight of the responsible authority created conditions for 
a normal activity in the banking system. This fact helped banks create financial and human capacities, which under the impact of the increase of competition materialised in the increase of the crediting activity for economy. On the other hand, increase of competition and loan was associated with the deepening activity of the bank mediator, which is noted in the number of products offered, in the geographic expansion, etc.

Developments in the banking system are expected to be transmitted also into the real sector of economy. By providing more products and services, banks help their clients in the process of saving and investment, thus stimulating economic growth. In addition, the banking system may improve the environment where domestic and international companies are operating as well as stimulate accession of the foreign capital in the country. But, on the other hand, the large increase of loans increase the scale of risk. The loan trend, in general, pursues the trend of economy, high in expansion and low in recession, in the meantime, performance measurements have same attitude, but different direction.

Therefore, the risks banks are taking at this stage, which is considered as the stage of economic growth, will be completely recorded at the moment when economic activity slows down. The banking institutions themselves are subject to individual crises, as a result of adverse selections or of the situation itself at risk, they are included in.

Under these conditions, it is indispensable to intervene in time and with maturity by the oversight monetary authorities, in order to keep under control the negative consequences, and streamlining the developments towards stable growth.

\section{Recommendations}

Based on relevant management analyses and assessments and development of loans at the level of risk in Kosovo banks, we can establish that:

- Financial crises more often than not may have negative and unwanted consequences of the risky activities performed by banking institutions.

- Banks are administering daily activity, thus trying to find an optimum level between profit and assurance.

- There is another factor stimulating risk, the level of loan collateralisation, which serves as assurance source for the loan officers, thus making it to pay less attention to problems that the client may have. This phenomenon oscillates depending on the characteristics of the borrower and the experience of bank experience.

- Importance of the problem of asymmetry of information is decreased since the borrower is entitled to sell the collateral and to be compensated for potential losses, in case the borrowers fails to pay the loan.

- Generation and selling of information is done after the lender has obtained full information on the individuals or companies which are in need of financing.

- In relation to risks, there are also some other institutional factors which are recommended to institutions in order to act upon:

- improvement of crediting policies;

- improvement of the process of risk administration;

- strengthening internal control procedures;

- identification of problematic loans;

- increase of corporative government;

- related loans or related borrowers.

www.journals.cz

\section{REFERENCES}

CBRK, (2011). Annual report. ( $p, 44-55)$. Central Bank of the Republic Kosovo, Pristina, Kosovo.

CBRK, (2011). Financial stability and economic analysis. (No.2) Central Bank of the Republic of Kosovo, Pristina, Kosovo.

CBRK, (2011). Methods on monetary and financial statistics. Central Bank of the Republic of Kosovo, Pristina, Kosovo.

CBRK, (2011). Regulation on management of loan risk. (p,7). Centra Bank of the Republic of Kosovo, Pristina, Kosovo.

ECB, (2003). Manual on MFI Interest rate statistics regulation 2001/18. European Central Bank (October), Frankfurt, Germany.

Pickett, K.H. Spencer, (2005). Auditing the Risk Management Process. New Jersey. John Wiley \& Sons, Inc. 